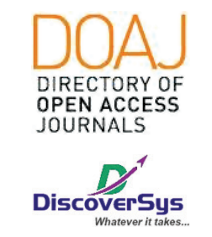

Published by DiscoverSys

\section{Gambaran karakteristik kanker anak di RSUP Sanglah, Bali, Indonesia periode 2008-2017}

\author{
Yohannes Adinatha, ${ }^{*}$ Ketut Ariawati
}

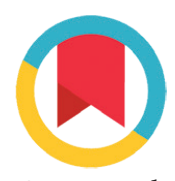

CrossMark

\title{
ABSTRACT
}

Background: Childhood cancer is estimated to increase every year. Child cancer divided into leukemia and solid tumors. In RSCM Jakarta, the most common cancers are Acute Leukemia, Brain Tumor (10-15\%), Retinoblastoma (10-12\%), and other malignancies. This study aims to determine the characteristics of childhood cancer at Sanglah General Hospital Denpasar in the period 2008-2017.

Method: A cross-sectional retrospective descriptive study was conducted by taking patient's medical records of leukemia and solid tumors data in children admitted to Sanglah General Hospital during 2008-2017. The parameters assessed in this study were the type of cancer in children, age, sex, or residence domicile. Data were analyzed with SPSS software version 17 for Windows.
Results: The results obtained 410 pediatric cancer patients during the 2008-2017 time period, which consisted of 240 cases of leukemia (58.5\%) and 170 cases of solid tumors (41.5\%). Most cases were $0-5$ years old $(61.5 \%)$, males (50.7\%), and domiciled in Bali (72.4\%). Acute lymphoblastic leukemia (LLA) is the most common hematologic malignancy in children, which occupies $41.0 \%$ of total cancers proportion, followed by retinoblastoma (14.0\%), malignant lymphoma (9.0\%), and neuroblastoma (5.0\%).

Conclusion: Most cancers in children occur at the age of 0-5 years, male sex, and domicile in Bali. Besides, acute lymphoblastic leukemia (LLA) is the most common hematologic malignancy in children.

Keywords: Characteristics, Cancer, Child, Sanglah General Hospital

Cite This Article: Adinatha, Y., Ariawati, K. 2020. Gambaran karakteristik kanker anak di RSUP Sanglah, Bali, Indonesia periode 2008-2017. Intisari Sains Medis 11(2): 575-581. D0l: 10.15562/ism.v11i2.638

\section{ABSTRAK}

Latar Belakang: Penyakit kanker anak diperkirakan meningkat setiap tahunnya. Kanker anak secara garis besar dibagi dua, yaitu keganasan darah (leukemia) dan tumor padat. DI RSCM Jakarta, kanker tersering yaitu Leukemia Akut, Tumor Otak (10-15\%), Retinoblastoma (10-12\%), dan keganasan lainnya. Penelitian ini bertujuan untuk mengetahui karakteristik kanker anak di RSUP Sanglah Denpasar dalam perioder 2008-2017.

Metode: Penelitian deskriptif retrospektif potong lintang dilakukan dengan pengambilan data rekam medis pasien leukemia dan tumor padat anak yang menjalani perawatan di RSUP Sanglah Denpasar periode tahun 2008-2017. Parameter yang dinilai pada penelitian ini adalah jenis kanker pada anak, usia, jenis kelamin, maupun domisili tempat tinggal. Data

Departemen IImu Kesehatan Anak, Fakultas Kedokteran, Universitas Udayana, RSUP Sanglah, Bali, Indonesia

*Korespondensi: Yohannes Adinatha, Departemen Ilmu Kesehatan Anak, Fakultas Kedokteran, Universitas Udayana, RSUP Sanglah, Bali, Indonesia;

yohannesadinatha@gmail.com

Diterima: 06-10-2019

Disetujui: 10-03-2020

Diterbitkan: 01-08-2020

dianalisis dengan piranti lunak SPSS versi 17 untuk Windows.

Kata Kunci: Karakteristik, Kanker, Anak, RSUP Sanglah Sains Medis 11(2): 575-581. D0I: 10.15562/ism.v11i2.638

\section{PENDAHULUAN}

Penyakit kanker merupakan salah satu penyebab kematian utama di seluruh dunia. ${ }^{1}$ Di Amerika Serikat, kanker berada pada urutan kedua dari sepuluh penyebab kematian anak dibawah usia 9 tahun tahun 2012 dengan presentasi 12.7\%,

Hasil: Hasil penelitian mendapatkan 410 pasien kanker anak selama rentang waktu 2008-2017 dimana terdiri atas 240 kasus leukemia (58,5\%) dan 170 kasus tumor padat (41.5\%). Sebagian besar kasus berusia 0-5 tahun $(61,5 \%)$, berjenis kelamin laki-laki $(50,7 \%)$, dan berdomisili di Bali $(72,4 \%)$. Leukemia Limfoblastik Akut (LLA) merupakan keganasan hematologi tersering pada anak dimana menempati proposi $41,0 \%$ dari total kanker, diikuti Retinoblastoma (14,0\%), Limfoma maligna $(9,0 \%)$, dan Neuroblastoma $(5,0 \%)$.

Kesimpulan: Sebagian besar kanker pada anak terjadi pada usia 0-5 tahun, berjenis kelamin laki-laki, dan domisili di Bali. Di samping itu, Leukemia Limfoblastik Akut (LLA) merupakan keganasan hematologi anak tersering pada anak.

Cite Pasal Ini: Adinatha, Y., Ariawati, K. 2020. Gambaran karakteristik kanker anak di RSUP Sanglah, Bali, Indonesia periode 2008-2017. Intisari

urutan pertama sebesar 32\% disebabkan oleh kecelakaan dan cedera. ${ }^{1}$ Menurut data Global Cancer Statistic (GLOBOCAN) 2018, kanker anak menyumbang $1 \%$ dari total kanker diseluruh dunia, dan kejadiannya berkisar antara 50 hingga 
180 per juta jiwa per tahun. ${ }^{2}$ Diperkirakan 198.700 kasus kanker baru akan terjadi pada anak berusia 0-14 pada tahun 2018. ${ }^{1,2}$ Data statistik resmi dari International Agency of Reasearch Cancer (IARC), memperkirakan bahwa sebanyak $80 \%$ anak yang terdiagnosis kanker berada di negara berkembang. ${ }^{1,2}$ Di Indonesia terdapat sekitar 11.000 kasus kanker anak setiap tahunnya, dan terdapat sekitar 650 kasus kanker anak di Jakarta. ${ }^{3}$

Jenis penyakit kanker anak cenderung berbeda dengan kanker pada dewasa. Secara garis besar, kanker pada anak dibagi atas dua bagian, yaitu kanker hematolgi (leukemia), dan tumor padat. ${ }^{4}$ Secara umum, sepertiga dari kanker anak adalah leukemia. ${ }^{2}$ Hingga kini, penyebab terjadinya kanker pada anak tidak diketahui secara pasti namun umumnya beberapa faktor risiko kanker anak yang dapat diidentifikasi, di antaranya adalah radiasi, faktor genetik, kelainan kromosom atau adanya mutasi DNA, pekerjaan orang tua serta keadaan sosial ekonomi karsinogen kimiawi, dan virus (Epstein-Barr, Hepatitis B, Human Herpes dan $H I V){ }^{2}$

Secara epidemiologi, kejadian leukemia sebesar 30-40\% dari seluruh keganasan pada anak, dengan puncak usia 2-5 tahun. ${ }^{3}$ Leukemia merupakan bentuk kanker yang paling sering di antara anakanak di sebagian besar negara. Namun, negara di Sub-Sahara Afrika, Limfoma merupakan kejadian kanker anak terbanyak. Kanker anak yang umum lainnya seperti tumor otak (20\%) dan limfoma (12\%). Insiden kanker anak di China 87,1 juta kasus per tahun, dengan 49,5\% disebabkan leukemia, dan diikuti dengan tumor otak $(17,6 \%){ }^{2}$ Di RSCM Jakarta, Leukemia merupakan jenis kanker yang paling banyak ditemukan pada anak kurang dari 15 tahun (30-40\%) diikuti tumor otak (10-15\%), Retinoblastoma (10-12\%), Sementara di RS dr. Sardjito UGM didapatkan 30-40 Leukemia anak didiagnosis setiap tahunnya. ${ }^{4}$

Mayoritas anak yang menderita kanker tinggal di negara berkembang dengan segala permasalahnnya seperti angka kesintasannya yang masih rendah. Hal ini sebagian besar disebabkan karena lebih dari 60\% kasus kanker anak yang datang ke fasilitas kesehatan sudah stadium lanjut. Permasalahan lain seperti ketidaktahuan keluarga tentang kanker, keterbatasan finansial, keterbatasan akses tempat pelayanan kanker, rendahnya tingkat pendidikan orangtua. ${ }^{5}$

Dengan mengetahui angka kejadian kanker anak, usia tersering dan gejala dari kanker, diharapkan tenaga medis mampu mendiagnosis dan memberikan terapi lebih awal. Berkaitan dengan hal tersebut maka penelitian ini bertujuan untuk mengetahui karakteristik kanker anak khususnya yang terjadi di RSUP Sanglah Denpasar selama periode 2008-2017.

\section{METODE PENELITIAN}

Penelitian ini menggunakan pendekatan potong lintang dengan desain deskriptif retrospektif terhadap semua pasien kanker yang dirawat di bangsal anak RSUP Sanglah Denpasar pada periode tahun 2008-2017. Populasi target adalah anak yang menderita kanker. Populasi terjangkau adalah anak yang menderita kanker yang dirawat di RSUP Sanglah selama periode 2008-2017. Kriteria inklusi penelitian ini adalah anak usia 0 hari-12 tahun yang didiagnosis kanker dan tercatat dalam register pasien baru kanker darah dan tumor padat Departemen Ilmu Kesehatan Anak RSUP Sanglah Denpasar pada tahun 2008-2017. Kriteria eksklusi adalah data register penderita yang tidak lengkap.

Besar sampel ditetapkan menggunakan rumus sampel tunggal untuk estimasi proporsi suatu populasi menggunakan ketepatan absolut $10 \%$, dengan $P$ 60\%, kesalahan tipe I 0,05 dan didapatkan jumlah sampel 92 orang. Peneliti mengambil sampel sesuai dengan kriteria inklusi dan ekslusi. Data dikumpulkan dalam periode 10 tahun (Januari 2008 sampai Desember 2017). Penelitian ini dilakukan dibawah pengawasan Divisi Hematologi-Onkologi Departemen Ilmu Kesehatan Anak FK UNUD/ RSUP Sanglah.

Pada penelitian ini, karakteristik kanker anak yang dicari berupa jenis kanker, usia saat terdiagnosis, jenis kelamin, domisili pasien. Data diperoleh dari penderita yang telah terdiagnosis dan tercatat dalam register pasien hematologi-onkologi periode Januari 2008 sampai Desember 2017. Leukemia merupakan kanker hematologi yang berasal dari sumsum tulang dengan proliferasi sel-sel darah putih ditandai gejala klinis seperti demam, pucat, limpadenopati, hepato-splenomegali disertai gangguan hematologi (anemia, neutropenia, trombositopenia). Leukemia dibagi menjadi Leukemia Limfoblastik Akut (LLA), Leukemia Mieloblastik Akut (LMA) Leukemia Mieloblastik Kronik (LMK), Limfoma Non-Hodgkin (LNH) dan Limfoma Hodgkin (LH). Tumor padat ganas (solid tumor) merupakan keganasan dari organ tubuh selain darah. Retinoblastoma adalah tumor padat ganas di dalam bola mata yang berkembang dari sel retina primitive. Neuroblastoma adalah tumor padat embryonal dari sistem saraf pusat simpatis dari primitive neural crest. Tumor Wilms merupakan tumor ganas embrional ginjal yang berasal dari metanefros. Sarkoma merupakan keganasan yang berasal dari mesenkimal, dapat mengenai jaringan lunak yang akan berkembang menjadi 
Rabdomiosarkoma serta mengenai tulang (tumor tulang malignan). Tumor Sel Germinal merupakan keganasan dari sel germinal primitive yang akan berdiferensiasi menjadi sel telur maupun sperma. Histisitosis Sel Langerhans (HSL) merupakan keganasan yang terjadi akibat proliferasi dan inflitrasi dari sistem sel fagosit mononuclear dan dendritik yang akan terakumulasi dalam jaringan ikat. Diagnosis pasti dari tumor padat adalah pemeriksaan histopatologi maupun imunohistokimia. Dalam penelitian ini, umur anak dinyatakan dalam tahun. Jenis kelamin terbagi menjadi 2 yaitu laki dan perempuan. Domisili merupakan daerah asal atau tempat kediaman resmi penderita (sesuai kartu tanda penduduk). Seluruh data yang diperoleh dianalisis dengan piranti lunak SPSS versi 17 untuk Windows.

\section{HASIL PENELITIAN}

Dalam kurun waktu 10 tahun (Januari 2008-Desember 2017) didapatkan 410 pasien anak terdiagnosis kanker di RSUP Sanglah Denpasar yang terdiri dari kanker hematologi sebanyak 208 kasus $(50,7 \%)$ dan tumor padat 202 kasus (49,3\%). Karakteristik sampel dapat dilihat pada Tabel 1. Hasil penelitian ini juga menunjukkan bahwa sebagian besar anak yang mengidap kanker selama periode penelitian adalah berjenis kelamin

\section{Tabel 1 Karakteristik kanker anak di RSUP Sanglah Denpasar} periode 2008-2017

\begin{tabular}{lcc}
\hline Karakteristik & Jumlah (N=410) & Persentase (\%) \\
\hline Usia & 252 & \\
$0-5$ tahun & 128 & 61,5 \\
6-10 tahun & 30 & 31,2 \\
>10 tahun & & 7,3 \\
Jenis kelamin & 224 & \\
Laki-laki & 186 & 54,6 \\
Perempuan & & 45,4 \\
Jenis kanker & 240 & \\
Hematologi & 170 & 58,5 \\
Tumor padat & & 41,5 \\
Domisili & 297 & \\
Bali & 86 & 72,4 \\
NTB & 16 & 20,9 \\
NTT & 4 & 3,9 \\
Sulawesi tengah & 2 & 0,9 \\
Jawa timur & 1 & 0,4 \\
Palembang & 1 & 0,2 \\
Bandung & 3 & 0,2 \\
Timor Timur & & 0,7 \\
\hline
\end{tabular}

laki-laki (54,6\%), jenis kanker hematologi (58,5\%), dan domisili di Bali (72,4\%) (Tabel 1). Gambar 1 menunjukkan bahwa kasus yang terdiagnosis kanker anak sejak tahun 2008 sampai dengan 2017 di RSUP Sanglah cenderung meningkat, dengan peningkatan paling tinggi terjadi pada tahun 2014 yaitu 55 kasus.

Proporsi kanker anak selama periode 10 tahun (Gambar 1), didominasi terutama oleh kanker hematologi 240 kasus (58,5\%) dengan angka kejadian terbanyak merupakan Leukemia Limfoblastik Akut 166 kasus (41\%). Sedangkan untuk tumor padat, dengan proporsi sebanyak 170 kasus $(41,5 \%)$ dengan 3 kelompok tumor padat terbanyak yaitu Retinoblastoma 57 kasus (14\%), neuroblastoma 22 kasus (5\%) (Gambar 1).

Angka kejadian kanker hematologi dan tumor padat berdasarkan jenis kelamin laki dan perempuan ditampilkan pada Gambar 3A dan 3B. Hasil penelitian menunjukkan bahwa jenis kelamin laki-laki mendominasi proporsi kanker hematologi jenis Leukemia Mieloblastik Akut (10,0\%), Limfoma Non-Hodgkin (5,83\%), dan Limfoma Hodgkin (1,67\%) dibandingkan perempuan (Gambar 3A). Sedangkan pada tumor padat anak jenis kelamin laki-laki mendominasi pada retinoblastoma (19,41\%), neuroblastoma (7,05\%), rhabdomiosarkoma (7,05\%), Ewing Sarkoma (3,53\%), meduloblastoma (3,53\%), dan Langerhans sel histiositosis (2,35\%) (Gambar 3B).

Angka kejadian kanker anak berdasarakan usia dibagi menjadi 3 kelompok yaitu usia 0-5 tahun, 6-10 tahun dan diatas 10 tahun ditampilkan pada Gambar 4A dan 4B. Hasil penelitian ini menunjukkan bahwa proporsi usia anak 0-5 tahun dominan pada kanker hematologi jenis Leukemia Limfoblastik Akut, Leukemia Mieloblastik Akut, dan Limfoma Non-Hodgkin (Gambar 4A). Berdasarkan tumor padat anak usia anak 0-5 tahun mendominasi pada kasus retinoblastoma, neuroblastoma, tumor Wilms, rabdomiosarkoma, tumor sel germinal, osteosarkoma, hepatoblastoma, dan Langerhans sel histiositosis (Gambar 4B)

\section{PEMBAHASAN}

Menurut data Union for International Cancer Control (UICC) setiap tahun terdapat sekitar 176.000 anak yang terdiagnosis kanker, yang mayoritas berasal dari negara berpenghasilan rendah, dan menengah. ${ }^{5}$ Sementara itu, di Indonesia terdapat sekitar 11.000 kasus kanker anak tiap tahunnya, dan terdapat sekitar 650 kasus kanker di Jakarta, sedangkan di RSUD Soetomo, Surabaya pada tahun 2016 sebanyak 252 kasus. ${ }^{1,6}$ Pada penelitian ini tercatat kanker anak yang terdiagnosis sejak tahun 2008 sampai 2017 sebanyak 410 kasus. Selain faktor 


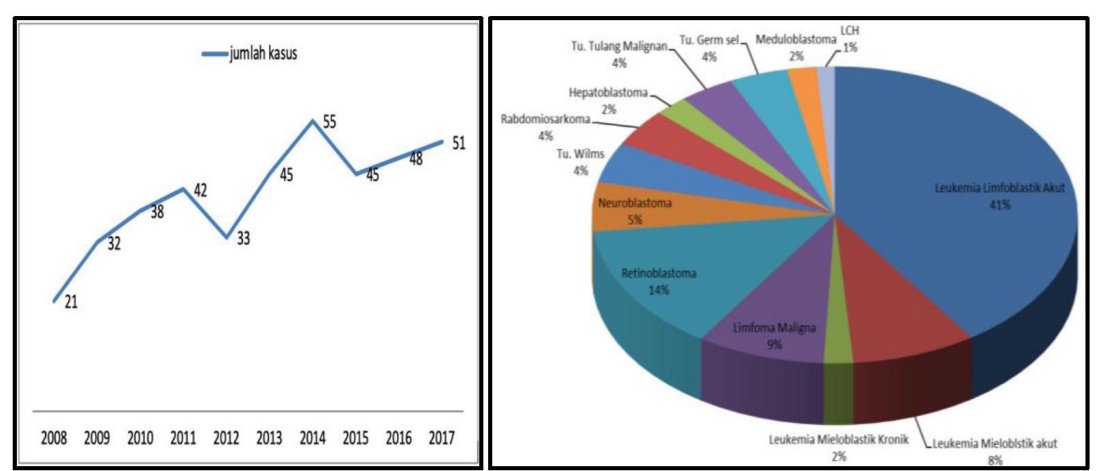

Gambar 1 Distribusi Kanker Anak dan Pola Kanker di RSUP Sanglah Denpasar tahun 2008-2017

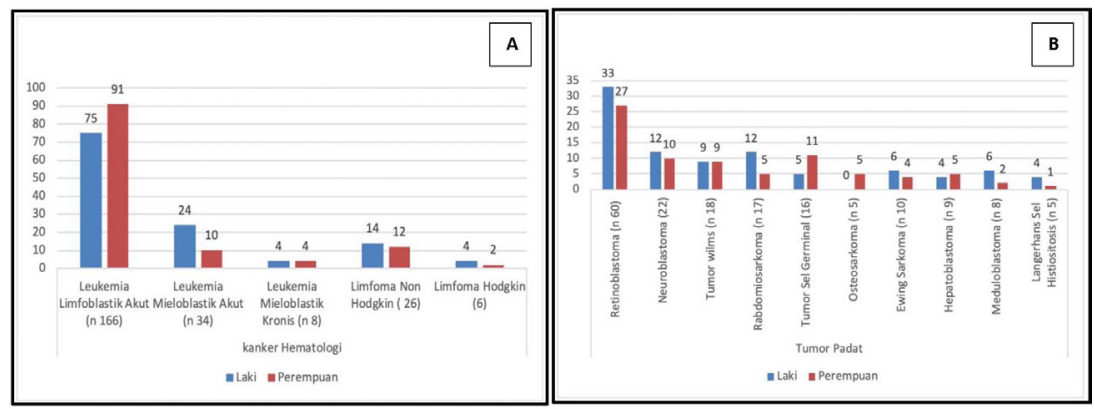

Gambar 3 Angka Kejadian Kanker (A) Hematologi dan (B) Tumor Padat Anak Berdasarkan Jenis Kelamin

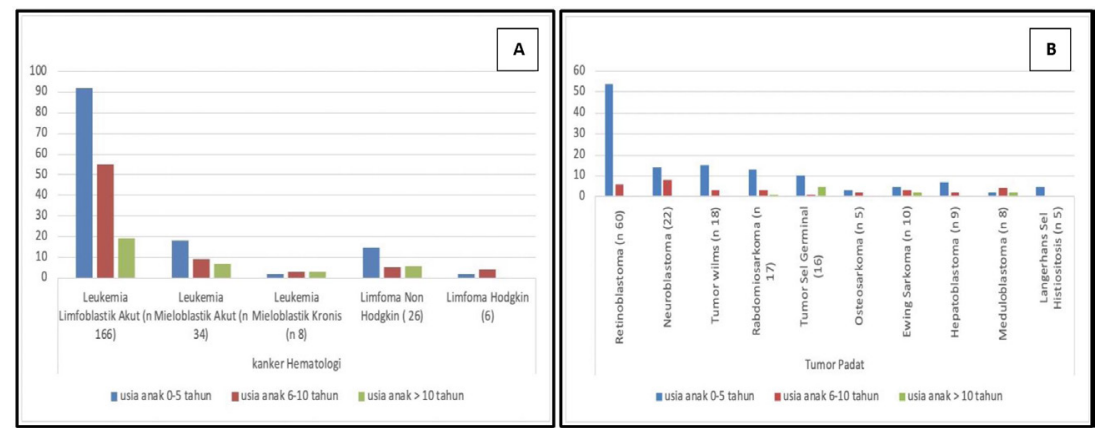

Gambar 4 Angka Kejadian (A) Kanker Hematologi dan (B) Tumor Padat Anak Berdasarkan Usia

risiko kejadian kanker seperti radiasi, faktor genetik, kelainan kromosom, perbedaan angka kejadian kanker di tiap daerah dapat dipengaruhi oleh faktor ekomoni, tingkat pendidikan orangtua, akses menuju tempat pelayanan kesehatan yang sulit. ${ }^{7}$

Karakteristik kanker anak di RSUP Sanglah berdasarkan usia didapatkan usia terbanyak adalah kurang dari 5 tahun yaitu 252 pasien $(61,5 \%)$ dan terendah pada kelompok usia lebih dari 10 tahun yaitu 30 pasien (7,3\%). Menurut Sistem Registrasi Kanker di Indonesia (SriKanDI), anak usia 0-5 tahun angka kejadiannya lebih tinggi yaitu 18 per 100.000 anak, sedangkan pada usia 6-14 tahun 10 per 100.000 anak. ${ }^{8}$ Berdasarkan pola domisili, selain Bali, provinsi NTB dan NTT berada pada urutan kedua dan ketiga, masing-masing sebanyak 86 (20.9\%) dan 16 (3,9\%) dimana RSUP Sanglah merupakan salah satu rumah sakit rujukan untuk wilayah Indonesia timur.

Berdasarkan distribusi kanker, terjadi peningkatan jumlah pasien yang terdiagnosis tiap tahunnya, dengan puncak tertinggi pada tahun 2014 sebanyak 55 kasus. Hasil serupa juga didapatkan pada penelitian Kanker anak di RSK Dharmais sejak tahun 2006-2014 terjadi peningkatan kasus dengan kasus terbanyak pada tahun 2014 sebanyak 144 kasus. $^{8}$ Diharapkan, dengan adanya Jaminan Kesehatan Nasional (JKN) yang mulai berjalan per 1 Januari 2014 mampu memberikan pelayan yang komprehensi bagi pasien kanker anak.

Data sebaran kanker di Indonesia masih terbatas. Dengan mengetahui sebaran kanker yang ada, diharapkan dapat menjadi acuan dalam penanggulangan serta penyediaan sarana dan prasana yang memadai. Pada penelitian ini, proporsi kanker terbanyak yaitu Leukemia Limfoblastik Akut (LLA) yaitu 166 kasus (40,5\%). Hasil penelitian ini sesuai dengan penelitian yang dilakukan di RSCM, ditemukan bahwa leukemia merupakan jenis kanker yang paling banyak terjadi pada anak dengan umur di bawah 15 tahun (30-40\%). ${ }^{8}$ Penelitian yang dilakukan di RSK Dharmais dan Dr. Sardjito Universitas Gajah Mada, masingmasing menemukan rata-rata 10 dan 30 LLA kasus baru tiap tahunnya, sementara di RSU Dr. Soetomo dan RSUP Sanglah sepanjang tahun 2002 dijumpai 70 kasus Leukemia baru. ${ }^{8,9}$ Urutan kedua terbanyak pada penelitian ini yaitu Retinoblastoma sebanyak 57 kasus (13,9\%), selanjutnya limfoma maligna 35 kasus $(8,5 \%)$ dan neuroblastoma 22 kasus $(5,4 \%) .{ }^{9}$ Hasil ini berbeda dengan penelitian di RSCM yaitu tumor otak menduduki peringkat kedua (10-15\%), diikuti Retinoblastoma (10-12\%) selanjutnya Limfoma maligna. ${ }^{9}$ Hal ini disebabkan pasien dengan kecurigaan tumor otak lebih dahulu datang ke bagian spesialis bedah saraf RSUP Sanglah untuk tindakan kecuali pasien yang memerlukan tatalaksana medikamentosa/ kemoterapi.

Berdasarkan karakteristik kanker hematologi penelitian ini, didapatkan LLA 166 kasus $(79,8)$ dengan dominansi jenis kelamin laki yaitu 91 kasus (54\%) dan usia terbanyak antara 2-10 tahun, sebesar 144 kasus (86,7\%). Penelitian ini sesuai dengan penelitian Sulastriana dkk tahun 2013 di Medan, yaitu predominan penderita lelaki dari perempuan..$^{10}$ Masih belum jelas alasan kasus LLA lebih banyak terjadi pada lelaki. Perbedaan jenis kelamin ini mempengaruhi prognosis, dimana lelaki mempunyai prognosis yang lebih buruk dibandingkan jenis kelamin perempuan. Hal ini disebabkan oleh karena pada lelaki dapat terjadi keterlibatan testis pada $10-23 \%$ kasus. ${ }^{9,10}$ 
Limfoma maligna adalah kanker hematologi primer jaringan limfoid yang bersifat padat dimana penyakit ini dibagi dalam 2 golongan besar, yaitu penyakit Hodgkin dan limfoma non-Hodgkin (LNH). ${ }^{11}$ Walaupun angka kejadian limfoma maligna di Indonesia belum pasti, namun merupakan kanker tumor padat yang sering ditemukan pada anak, hampir sepertiga dari kanker pada anak setelah leukemia dan kanker susunan saraf pusat. ${ }^{11}$ Sebanyak $60 \%$ limfoma maligna pada anak dan remaja merupakan LNH. Kejadian tertinggi LNH pada umur 7-10 tahun dan jarang dijumpai pada usia dibawah 2 tahun. ${ }^{12}$ Sementara untuk LH ditemukan perbandingan laki-laki dengan perempuan sebesar 4:2, dengan usia tersering pada 6-10 tahun sebesar $66,7 \%$ pada penelitian ini. Hal ini serupa dengan hasil penelitian lainnya, dikatakan LNH banyak mengenai anak $<14$ tahun dan lebih sering pada jenis kelamin laki dibandingkan wanita, 2,5:1, sedangkan untuk LH angka kejadian dikatakan lebih sering pada laki dan mempunyai kurva bimodal yang khas, dengan salah satu puncaknya pada usia 15-35 tahun yang ikuti dengan puncak lainnya pada usia 45-55 tahun. ${ }^{12,13}$

Retinoblastoma merupakan tumor intra-okular primer yang paling banyak ditemukan. ${ }^{14}$ Bukti paling awal dari tumor ini adalah reflek putih, atau yang dikenal sebagai reflek mata kucing (cat eyes reflex) atau leukocoria. ${ }^{14}$ The Third National Cancer Survey mengemukakan bahwa di Amerika Serikat, rata-rata insiden Retinoblastoma adalah 11 kasus per 1 juta jiwa populasi usia kurang dari 5 tahun, atau 1 diantara 18.000 kelahiran hidup. ${ }^{15}$ Di RSCM Jakarta ditemukan 15-22 kasus per tahun sebelum tahun 2002, dan meningkat setiap tahunnya hingga 40 kasus pada tahun 2002-2003. ${ }^{16}$ Pada penelitian ini didapatkan 60 kasus dalam periode 10 tahun, dengan angka kejadian laki berbanding perempuan hampir sama.

Neuroblastoma merupakan salah satu tumor embrional dari sistem saraf simpatis yang berasal dari primitive neural crest. ${ }^{17}$ Perjalanan penyakit pada beberapa neuroblastoma ada yang membaik secara spontan dan sebagian bisa sembuh dengan pemberian kemoterapi dan yang lainnya resisten dengan kemoterapi yang intensif sekalipun. ${ }^{17}$ Penelitian Garniasih RD dkk melaporkan antara tahun 2000-2007 tercatat 62 pasien baru Neuroblastoma $(5,76 \%)$ dari seluruh kanker anak di FKUI/RSCM Jakarta. ${ }^{18}$ Puncak insiden terjadi pada usia antara 0-4 tahun dengan rata-rata usia 2 tahun. Pada penelitian ini, ditemukan kejadian neuroblastoma sebanyak 17 kasus $(4,1 \%)$, lebih banyak pada jenis kelamin laki yaitu 12 pasien (54,5\%) dengan angka kejadian terbanyak pada usia $0-5$ tahun yaitu 14 kasus $(63,7 \%) .^{18}$
Tumor Wilms adalah tumor ganas embrional ginjal yang berasal dari metanefros. ${ }^{19}$ Sekitar $80 \%$ tumor ini terjadi pada anak di bawah 6 tahun, dengan puncak insiden pada usia 2-4 tahun. ${ }^{19}$ Tumor Wilms terhitung $6 \%$ dari seluruhnya penyakit kanker pada anak dimana perbandingan insiden laki dan perempuan hampir sama. ${ }^{19}$ Adanya massa dalam perut merupakan gejala tumor Wilms yang paling sering (75-90\%), yang sebagian besar diketahui pertama kali oleh orangtua pasien. ${ }^{19}$ Hasil serupa juga tampak pada penelitian ini, ditemukan pasien Tumor Wilms sebanyak 18 kasus (4,3\%) dengan usia terbanyak pada usia antara 0-5 tahun yaitu 15 kasus $(83,3 \%)$ dengan perbandingan jenis kelamin laki banding perempuan sama (9:9).

Pada penelitian ini, didapatkan kejadian Rabdomiosarkoma (RMS) sebanyak 17 kasus $(4,1 \%)$ dimana jenis kelamin laki lebih banyak dibanding perempuan yaitu 12:5. Penelitian Rini AT dkk tahun 2000-2008 juga mendapatkan hasil serupa yaitu 44 pasien dengan perbandingan laki:perempuan adalah 2:1 dan kebanyakan menyerang anak usia 3 bulan - 5 tahun yaitu 21 pasien $(47,7 \%){ }^{20}$ Rabdomiosarkoma adalah kanker jaringan lunak yang paling sering pada anak dengan derajat keganasan tinggi dan diperkirakan timbul dari sel-sel mesenkimal primitive yang kemudian hari menjadi otot lurik, dapat timbul pada semua bagian tubuh kecuali pada tulang. ${ }^{21}$ Sekitar $15 \%$ anak dengan RMS datang dalam keadaan metastasis dan prognosisnya tidak ada perbaikan dalam 15 tahun terakhir. ${ }^{20,21}$

Tumor Sel Germinal (TSG) merupakan kanker yang berkembang dari sel germinal primordial embrional, yang normalnya berfungsi untuk menghasilkan sperma atau sel telur. ${ }^{22}$ Tumor ini merupakan tumor anak yang jarang, hanya 2-3\% dari kanker pada anak di bawah usia 15 tahun, dijumpai pada 2 kelompok usia yaitu pada bayi dan remaja/pubertas. ${ }^{23}$ Pada penelitian ini didapatkan hasil yang serupa yaitu terdapat 15 pasien $(3,6 \%)$ TSG dengan usia terbanyak kurang dari 5 tahun $(62,5 \%)$ dan meningkat kembali usia diatas 10 tahun $(31,2 \%)$.

Tumor tulang maligna berkontribusi sekitar 6\% dari seluruh kanker anak. ${ }^{24}$ Penelitian yang dilakukan Sihombing dkk di RSCM Jakarta pada tahun 1998-2008 mendapatkan 23 pasien dengan usia tersering pada $>10$ tahun yaitu 18 kasus $(78,3 \%)$, terdiri dari 16 laki $(69,5 \%)$ dan 7 perempuan $(30,5 \%){ }^{25}$ Hasil yang berbeda didapatkan pada penelitian ini, yaitu didapatkan 5 kasus Osteosarkoma dengan mayoritas jenis kelamin perempuan (100\%) dan terbanyak pada usia $<10$ tahun (60\%). Hal ini disebabkan, batasan usia anak di RSUP Sanglah pada tahun 2008-2017 
masih usia $\leq 12$ tahun, sehingga sebagian besar pasien usia $>12$ tahun tidak tercatat dalam register pasien kanker anak. Ewing's sarcoma family tumors merupakan kelompok tumor yang terdIri dari sarkoma ewing, Primitive Neuroectodermal Tumors (PNET) yang terjadi di tulang dan jaringan lunak, serta tumor Askin. ${ }^{26}$ Penelitian di RSCM tahun 2000-2010 mendapatkan 26 kasus, dimana kanker ini menduduki peringkat 13 dari seluruh kanker anak dengan karakteristik usia lebih banyak terjadi pada $<10$ tahun yaitu $65,4 \%$, dengan perbandingan jenis kelamin perempuan lebih banyak yaitu 11:15. ${ }^{27}$ Sementara hasil berbeda ditemukan pada penelitian ini, dimana terdapat 10 kasus Ewing Sarkoma yang lebih banyak terjadi pada jenis kelamin laki dibandingkan perempuan yaitu 6:4, dengan usia terbanyak $<10$ tahun yaitu 7 kasus $(70 \%)$.

Pada penelitian ini didapatkan angka kejadian Hepatoblastoma, Meduloblastoma, dan Histiositosis adalah yang paling rendah. Kejadian Hepatoblastoma pada penelitian ditemukan pada laki dan perempuan dengan perbandingan 4:5 yang banyak terjadi antara usia 0-5 tahun $(77,8 \%)$. Hasil ini berbeda dibandingkan dalam beberapa penelitian sebelumnya, bahwa jenis kelamin laki memiliki risiko kejadian hepatoblastoma 1,7 kali lebih sering dibanding perempuan. Umur ratarata saat diagnosis ditegakkan untuk hepatoblastoma adalah 1 tahun dan kebanyakan terjadi pada 18 bulan pertama. ${ }^{28}$ Hepatoblastoma merupakan tumor yang jarang ditemukan, namun merupakan tumor ganas primer hati yang paling banyak pada masa kanak-kanak..$^{28}$ Data National Cancer Institute di AS menunjukkan 79\% dari seluruh kanker hati adalah hepatoblastoma. ${ }^{28}$

Meduloblastoma merupakan tumor otak yang paling sering ditemukan pada anak, yang merupakan $20 \%$ dari kejadian tumor otak anak dengan usia tersering sekitar $80 \%$ terjadi pada $<15$ tahun. ${ }^{29} \mathrm{Pada}$ penelitian ini, didapatkan 8 pasien $(100 \%)$ usia saat terdiagnosis antara usia 1-11 tahun. Histiositosis Sel Langerhans (HSL) merupakan penyakit hematologi yang jarang ditemukan, dengan karakteristik akumulasi dan infiltrasi sel monosit, makrofag, sel dendritik di jaringan dengan berbagai manifestasi. HSL dapat terjadi pada semua umur, dengan angka kejadian paling banyak pada usia 1 sampai 3 tahun, perbandingan laki dan perempuan adalah 2:1.30 Pada penelitian ini, didapatkan hasil yang serupa yaitu perbandingan jenis kelamin laki lebih besar dibandingkan perempuan $4: 1$, sementara untuk usia didapatkan terbanyak antara 0-5 tahun.

\section{SIMPULAN}

Leukemia anak merupakan kanker tersering pada kanker anak, khususnya Leukemia Limfoblastik
Akut (LLA) sebesar 42\%, disusul tumor padat yaitu Retinoblastoma (15\%), Limfoma maligna (9\%) dan Neuroblastoma (6\%).

\section{KONFLIK KEPENTINGAN}

Tidak terdapat konflik kepentingan dalam penulisan laporan penelitian ini.

\section{ETIKA PENELITIAN}

Penelitian ini telah mendapatkan ijin dari Komite Etik Fakultas Kedokteran Universitas Udayana dengan no. 84/UN.14.2/KEP/2018.

\section{PENDANAAN}

Tidak ada.

\section{KONTRIBUSI PENULIS}

YA dan KA memiliki kontribusi yang sama dalam penulisan laporan penelitian ini baik dari tahap penyusunan kerangka berpikir, pengumpulan data, analisis data penelitian, hingga interpretasi hasil penelitian dalam bentuk publikasi ilmiah.

\section{DAFTAR PUSTAKA}

1. Torre LA, Bray F, Siegel RL, Ferlay J, Lortet-Tieulent J, Jemal A. Global cancer statistics, 2012. CA Cancer J Clin. 2015;65(2):87-108.

2. Bray F, Ferlay J, Soerjomataram I, Siegel RL, Torre LA, Jemal A. Global cancer statistics 2018: GLOBOCAN estimates of incidence and mortality worldwide for 36 cancers in 185 countries. CA Cancer J Clin. 2018;68(6):394-424.

3. Handayani K, Sitaresmi MN, Supriyadi E, et al. Delays in diagnosis and treatment of childhood cancer in Indonesia. Pediatr Blood Cancer. 2016;63(12):2189-2196.

4. Saletta F, Seng MS, Lau LM. Advances in paediatric cancer treatment. Transl Pediatr. 2014;3(2):156-182.

5. Kaatsch P. Epidemiology of childhood cancer. Cancer Treat Rev. 2010;36(4):277-285.

6. Permono B, Ugrasena IDG, Supriyadi E. Leukemia akut. Dalam: Windiastuti, Nency MY, Mulatsih S, Sudarmanto B, Ugrasena IDG. Buku ajar hematologi-onkologi anak. Badan Penerbit IDAI. 2018: p.277-91.

7. Sharpe KH, McMahon AD, Raab GM, Brewster DH, Conway DI. Association between socioeconomic factors and cancer risk: a population cohort study in Scotland (1991-2006). PLoS One. 2014;9(2):e89513.

8. P2PTM Kementerian Kesehatan RI. Kenali gejala dini kanker pada anak. 2018. [Tersedia pada: http://www. p2ptm.kemkes.go.id/kegiatan-p2ptm/pusat-/kenaligejala-dini-kanker-pada-anak] [Diakses: 20 September 2019]

9. Tarigan ADT, Ariawati K, Widnyana P. Prevalensi dan karakteristik anak dengan leukemia limfoblastik akut tahun 2011-2015 di RSUP Sanglah Denpasar. Medicina. 2019;50(2):391-395.

10. Sulastriana, Muda S, Jemadi. Karakteristik anak yang menderita leukemia akut rawat inap di RSUP H. Adam Malik Medan tahun 2011-2012. Gizi, Kesehatan Reproduksi, dan Epidemiologi. 2013;2(6):1-9.

11. Huh J. Epidemiologic overview of malignant lymphoma. Korean J Hematol. 2012;47(2):92-104. 
12. Allen CE, Kelly KM, Bollard CM. Pediatric lymphomas and histiocytic disorders of childhood. Pediatr Clin North Am. 2015;62(1):139-165.

13. Mary HS, Howard W. Non-Hodgkin Lymphoma. Dalam: Philips Lanzkowsky. Manual of Pediatric Hematology and Oncology. Edisi keenam. London: Elsevier. 2016: p. 442-52.

14. Pandey AN. Retinoblastoma: An overview. Saudi J Ophthalmol. 2014;28(4):310-315.

15. Fernandes AG, Pollock BD, Rabito FA. Retinoblastoma in the United States: A 40-Year Incidence and Survival Analysis. J Pediatr Ophthalmol Strabismus. 2018;55(3):182-188.

16. Sayuti K, Aziz A, Nasrul M. Profil leukokoria pada anak di RSUP Dr. M. Djamil Padang. Majalah Kedokteran Andalas. 2014;37(1):38-43.

17. Ishola TA, Chung DH. Neuroblastoma. Surg Oncol. 2007;16(3):149-156.

18. Garniasih RD, Windiastuti E, Gatot D. Karakteristik dan Kesintasan Neuroblastoma pada Anak di Departemen Ilmu Kesehatan Anak Fakultas Kedokteran Universitas Indonesia Rumah Sakit Cipto Mangunkusumo. Sari Pediatri 2009;11(1): 39-46.

19. Szychot E, Apps J, Pritchard-Jones K. Wilms' tumor: biology, diagnosis and treatment. Transl Pediatr. 2014;3(1):12-24

20. Rini AT, Edhy K, Gatot D, Windiastuti E, Ciputra Y. Rabdomiosarkoma Pada Anak: Gambaran Klinis di 2 Institusi. Indonesian Journal of Cancer 2008;2(2):55-9.

21. Shern JF, Yohe ME, Khan J. Pediatric Rhabdomyosarcoma. Crit Rev Oncog. 2015;20(3-4):227-243.

22. Rescorla FJ. Pediatric germ cell tumors. Semin Surg Oncol. 1999;16(2):144-158.
23. Ariawati K, Widnyana AA. Tumor Sel Germinal. Dalam: Windiastuti, Nency MY, Mulatsih S, Sudarmanto B, Ugrasena IDG. Buku ajar hematologi-onkologi anak 2018. Badan Penerbit IDAI. 2018; p. 352-60.

24. Jackson TM, Bittman M, Granowetter L. Pediatric Malignant Bone Tumors: A Review and Update on Current Challenges, and Emerging Drug Targets. Curr Probl Pediatr Adolesc Health Care. 2016;46(7):213-228.

25. Sihombing Y Tumpal, Windiastuti E, Gatot D. Osteosarkoma pada anak di RS Dr. Cipto Mangunkusumo Jakarta. Sari Pediatri 2009;11(3):179-83.

26. Maheshwari AV, Cheng EY. Ewing sarcoma family of tumors. J Am Acad Orthop Surg. 2010;18(2):94-107.

27. Sari TT, Gatot D, Windiastuti E. Ewing's Sarcoma Family Tumor pada Anak (Keganasan Kelompok Sarkoma Ewing) di RS Cipto Mangunkusumo. Sari Pediatri 2011;13(2):117-22.

28. Ringoringo HP, Windiastuti E, Gatot D. Hepatoblastoma di Rumah Sakit Dr. Cipto Mangunkusumo Jakarta: Peran Kemoterapi Preoperatif. Sari Pediatri 2006;7(4):207-13.

29. Hanson RD, Atlas PM. Central Nervous System Malignancies. Dalam: Philips Lanzkowsky. Manual of Pediatric Hematology and Oncology. Edisi keenam. London: Elsevier. 2016: p. 464-6.

30. Arceci JR. Histiocytosis Syndromes. Dalam: Philips Lanzkowsky. Manual of Pediatric Hematology and Oncology. Edisi keenam. London: Elsevier. 2016: p. 407-18.

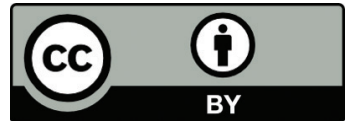

This work is licensed under a Creative Commons Attribution 